\title{
Implementation of Waste Electrical and Electronic Equipment Directive in Finland: Evaluation of the collection network and challenges of the effective WEEE management
}

\author{
Jenni Ylä-Mella a, ${ }^{*}$, Kari Poikela b, Ulla Lehtinen ${ }^{c}$, Riitta L. Keiski ${ }^{\mathrm{d}}$ and Eva Pongrácz a \\ a Centre of Northern Environmental Technology, Thule Institute, P.O. Box 7300, FIN-90014 University of Oulu, Finland \\ ${ }^{b}$ Kemin Digipolis Oy. Tietokatu 6, FIN-94600 Kemi, Finland \\ c Oulu Business School, P.O. Box 4600, FIN-90014 University of Oulu, Finland \\ a Mass and Heat Transfer Process Engineering, Faculty of Technology, P.O. Box 4300, \\ FIN-90014 University of Oulu, Finland
}

\begin{abstract}
Further to the European Waste Electrical and Electronic Equipment (WEEE) Directive, setting up efficient collection schemes is necessary to ensure the recovery targets set. Following the subsidiary principle, the WEEE Directive defines only the general requirements for mandatory collection and recycling objectives. The modalities of the logistics and the organisation of the take-back schemes are left to the choice of Member States. In this paper, the implementation of the WEEE Directive and the development of the WEEE recovery infrastructure in Finland are described and the challenges to the effective management of the WEEE recovery system in Finland are expressed. It can be said that the implementation of the WEEE Directive has succeeded in Finland and, at the same time, the legislative basis has been enacted. In addition, a functional WEEE recovery infrastructure has been built and, the collection requirements of the WEEE Directive have been exceeded in a relatively short time. However, the paper outlines that some inefficient practices still exist, particularly in the registration and collection stages. It is concluded that raising awareness would lead to a more environmentally sound behaviour and would, ultimately, improve WEEE recovery efficiency.
\end{abstract}

Keywords: WEEE Directive, National implementation, Producers associations, Collection, WEEE recovery network, Finland.

\footnotetext{
* Corresponding author. Tel.: +358 294487559

E-mail addresses: jenni.yla-mella@oulu.fi (J. Ylä-Mella), kari.poikela@digipolis.fi (K. Poikela), ulla.lehtinen@oulu.fi (U. Lehtinen), riitta.keiski@oulu.fi (R.L. Keiski), eva.pongracz@oulu.fi (E. Pongrácz)
}

\section{Introduction}

Waste represents an enormous loss of material and energy resources in the developed world, such as in the European Union (EU). As a result, the European Community has set its main objectives to preserve, protect and improve the quality of the environment and human health as well as utilising natural resources judiciously. Additionally, the Community programme of policy and action in relation to the environment and sustainable development states that the achievement of sustainable development calls for significant changes in current patterns of development, production, consumption and behaviour. It also calls for sustainable consumption and pollution prevention practices. To meet these objectives and ambitions, the EU has enacted a wide range of legislation to contribute to a sustainable waste management and use it as a key force for change. 
Production and use of electrical and electronic equipment (EEE) have significantly increased during the last three decades due to technological innovations and new applications of EEE. Fast technological progress and EEE becoming a part of everyday life have also led to the rapid growth of Waste Electrical and Electronic Equipment (WEEE). In order to adequately address the environmental problems associated with the treatment and disposal of WEEE and ensure the functioning of internal markets, the European Community implemented the WEEE Directive in 2003. The main aim of the WEEE Directive was to encourage producers to consider the design and production of EEE in relation to the end-of-life management; an approach that takes into account and facilitates their repair, possible upgrading, re-use, disassembly and recycling and, finally, the best methods of recovery and disposal.

The WEEE Directive was required to be transposed into national legislation by August $13^{\text {th }}, 2004$ and, further, a separate collection, treatment, recovery and environmentally sound disposal of WEEE had to be arranged and financed by producers by August $13^{\text {th }}, 2005$. To ensure the effectiveness of the WEEE collection network, a general separate collection target of $4 \mathrm{~kg} / \mathrm{inhab}$./year, as well as a recovery rate up to $80 \%$ and a recycling rate up to $75 \%$ had to be realized by December $31^{\text {st }}$, 2006, at the latest (Directive 2002/96/EC).

\subsection{The status quo of the WEEE Directive}

Numerous challenges arose during the implementation phase of the WEEE Directive, due to unequal development in operational and legislative progresses in the Member States. The experiences during the first years of the implementation of the WEEE Directive indicated also some technical, legal and administrative problems, which caused, e.g., continuing environmental harm, low levels of innovation in waste collection and treatment as well as the distortion of competition (European Commission, 2008). In 2010, it was estimated that less than half of the annually generated WEEE is separately collected and appropriately managed under the compliance schemes in the EU, varying from $1.2 \mathrm{~kg}$ in Romania to $17.2 \mathrm{~kg}$ per capita in Sweden (Eurostat, 2013; Huisman et al., 2007). Studies indicate that the rest of WEEE is collected and treated informally by unregistered enterprises or solid waste recyclers (Achillas et al., 2010; Papaoikonomou et al., 2009), illegally exported abroad (Li et al., 2013; Nnorom and Osibanjo, 2008; Torretta et al., 2013) or disposed with mixed waste into landfills (Bernstad et al., 2011; Darby and Obara, 2005; Gutiérrez et al., 2010; Melissen, 2006; Pérez-Belis et al., 2013). Moreover, a considerable portion of end-of-use EEE is still lying in homes or stocks waiting for a decision of final disposal (Chancerel, 2010; Gutiérrez et al., 2010; Ongondo and Williams, 2011; Pérez-Belis et al., 2013; Polák and Drápalová, 2012).

To improve WEEE recovery in EU, the WEEE Directive was revised in 2012 based on the experiences up until that point. The main tasks of revision were to clarify the scope, to improve the effectiveness through increased compliance, and to reduce free riding. Furthermore, the reduction of the environmental impacts by setting a more demanding collection, the re-use/recovery and recycling rates for WEEE were also in target. The recast of the WEEE Directive 2012/19/EU was signed on July $4^{\text {th }}, 2012$ and, in consequence, the initial WEEE Directive with its successive amendments will be revealed on February 15 $5^{\text {th }}, 2014$ (Directive 2012/19/EU).

Despite the essential and uniform requirements of the WEEE Directive to all Member States, the transpositions of the Directive into national legislations vary substantially. For instance, issues relating to the scope, range and type of producer responsibility, funding mechanisms and registration and monitoring are not particularly imposed by the Directive (Sinha-Khetriwal et al., 2006) and, therefore, more than 150 different 
compliance schemes exist in EU Member States (Sinha Khetriwal et al., 2011). National legislative implementations and/or the WEEE recovery networks have been investigated e.g. in the Netherlands (Melissen, 2006), UK (Turner and Callaghan, 2007), Denmark (Grunow and Gobbi, 2009), Greece (Achillas et al., 2010), Italy (Gamberini et al., 2008, 2009, 2010; Torretta et al., 2013), Germany (Walther et al., 2010), Sweden (Bernstad et al., 2011), Portugal (Gomes et al., 2011), Spain (Queiruga et al., 2012) and Romania (Torretta et al., 2013). However, there is no literature available on such study conducted in Finland.

\subsection{The aim of the study}

This paper is based on personal professional experiences and academic research conducted over the last 12 years in Finland. To the authors' knowledge, there is no other article dealing in this width with the Finnish WEEE recovery system, and there are practically no scientific papers in the subject in English. The aim of this paper was to provide an overview of the implementation of the WEEE Directive to Finnish legislation and, in addition, describe how the nationwide recovery infrastructure in Finland has been built. Furthermore, the main challenges of an effective management of the Finnish WEEE recovery network are expressed and, finally, current improvements in the Finnish legislation and in the WEEE management are introduced.

\subsection{The research methodology}

This study is explorative in nature and it rests on literature review, personal notifications and real-life experiences from Finland, collected over the course of 10 years. Notifications from representatives of authorities and WEEE operators were conducted either through personal encounters in professional positions, e-mail enquiries, or personal dialogues carried out during company visits, person-to-person discussions and in nationwide public events related to the topic of this work. While unstructured in its form, we believe the width and depth of experiences of the authors provide a unique view of the development process of the Finnish WEEE recovery system.

\section{The characteristics of Finland}

Finland is situated in the Northern Europe and has borders with Sweden to the west, Russia to the east, and Norway to the north. Further, Estonia lies to the south beyond the Gulf of Finland. Finland is the eighth largest country in Europe, with the total area of $338400 \mathrm{~km}^{2}$ (of which approximately $10 \%$ are inland waters). The distance between the southernmost to the northernmost points of Finland is almost $1200 \mathrm{~km}$.

At the end of the year 2012, Finland had 5.43 million inhabitants; the average population density of Finland is less than 18 inhab. $/ \mathrm{km}^{2}$, making Finland the third most sparsely populated country in Europe after Norway and Iceland. In the European Union, Finland is the most sparsely populated country. The majority of Finns live in the southern and western parts of the country (see Table 1). The most populous area is the Helsinki Capital Region (cities of Helsinki, Espoo, Vantaa and Kauniainen) in the southern coast, with more than 1 million inhabitants in total at the beginning of 2013. The other larger cities such as Tampere, Oulu and Turku have more than 180,000 inhabitants each. In addition to the cities, there are about 300 municipalities in Finland, half of which have fewer than 6000 residents. 
Table 1

Characteristics of Finnish regions in the end of 2012 (Statistics Finland, 2013).

\begin{tabular}{llll}
\hline Provinces & Population & Land area $\left[\mathrm{km}^{2}\right]$ & $\begin{array}{l}\text { Pop. density } \\
{[\text { inhab./km²] }}\end{array}$ \\
\hline 1 Southern Finland & $2,258,631$ & 29,897 & 75.5 \\
2 Western Finland & $1,907,930$ & 73,983 & 25.8 \\
3 Eastern Finland & 567,413 & 48,791 & 11.6 \\
4 Northern Finland & 481,355 & 57,008 & 8.4 \\
5 Lapland & 182,844 & 92,660 & 2.0 \\
6 Åland & 28,501 & 1552 & 18.4 \\
Finland & $5,426,674$ & 303,891 & 17.9 \\
\hline
\end{tabular}

\section{Legislative implementation of WEEE Directive in Finland}

\subsection{National legislation}

In accordance with the principle of subsidiarity, the WEEE Directive describes only the main principles of WEEE management and financing at a Community level, in order to avoid the distortion of internal markets. The modalities of the logistics and the organisation of take-back schemes are left to the choice of Member States. However, the WEEE Directive provided that national legislations in Member States on WEEE had to be implemented before August $13^{\text {th }}, 2004$. In addition, separate collection to ensure specific treatment and recycling of WEEE and suitable waste management facilities had to be developed by August $13^{\text {th }}, 2005$.

In Finland, producer responsibility had already been launched in the late 1990s through the management of waste tyres (Government Decree 1246/1995), packaging (962/1997) and paper (883/1998). However, in order to harmonize Finnish legislation with the requirements of the WEEE Directive, the Finnish Waste Act (1072/1993) had to be amended (452/2004) in June 2004 to include several new clauses on producer responsibility. In addition to the amendment of the Act, a Degree on Waste Electrical and Electronic Equipment (852/2004) was incorporated to the national legislation in September 2004. This meant that the national WEEE regulation fulfilling the obligations of the WEEE was implemented in Finland close to the duration of the transition period of the Directive. Currently, producer responsibility is also included in the waste management on end-of-life vehicles (581/2004) and on batteries and accumulators (422/2008).

According to the Finnish Waste Act 452/2004, producers of EEE were provided to organise the re-use, recovery and other waste management of the products they had put on the market, and were responsible for the costs incurred. In addition, producers had to ensure that an extensive network of collection facilities was established, to provide nationwide a reasonable opportunity to deliver end-of-life (EOL) products for recovery. Furthermore, sellers and other operators needed to be informed by producers with information and instructions on their products, their re-use, disassembly and recyclability of the components. Producers should also annually report on quantities and categories of electronics put on the market, the accumulation of discarded products and their collection, re-use, recovery, export and other waste management to the Centre for Economic Development, Transport and the Environment of Pirkanmaa (further ELY Centre Pirkanmaa), which acts as a national inspecting and controlling authority in Finland.

In 2011, the Finnish Waste Act was reformed due to incoherence caused by several amendments and, more importantly, because of the implementation of Waste Framework Directive (2008/98/EC). No outstanding changes in producer responsibility on EEE were done during the reformation process in 2011, however, roles and responsibilities of various actors were clarified and the mandate of the national inspecting and controlling 
authority was enhanced. The reformed Waste Act (646/2011) took effect on May $1^{\text {st }}, 2012$ with an exception of articles concerning producer responsibility (see Table 2), which entered into force on May $1^{\text {st }}, 2013$. The overview of the current realisation of Finnish WEEE legislation is outlined in Table 3.

\section{Table 2}

Sections related to producer responsibility of electronics, included in the Finnish Waste Act (646/2011) in 2011 (Ministry of the Environment in Finland, 2011).

\begin{tabular}{|c|c|}
\hline Section & Chapter 6 - producer responsibility \\
\hline $46-47$ & Producer's responsibilities and right of precedence to organise waste management \\
\hline 48 & Products and producers covered by producer responsibility \\
\hline 49 & Reception and transport of discarded products \\
\hline $51-52$ & Obligation of the producer to provide information on reception, measures for promoting re-use \\
\hline 53 & Exceptions to the cost liability of the producer for certain products \\
\hline $54-55$ & Obligation of the producer to keep records and provide information \\
\hline $56-57$ & Obligation of the product distributor to accept (discarded) products and provide information \\
\hline 61 & Financial guarantee required from the producer of electrical and electronic equipment \\
\hline $62-66$ & Establishment and requirements of a producer corporation \\
\hline 67 & Authorisation to implement by degree European Union provisions on producer responsibility \\
\hline Section & Chapter 11 - approval and entry in a waste management and producer register \\
\hline $101-105$ & Application, preconditions and approval in the producer register \\
\hline $106-107$ & Amendment of decision, revocation and expiry of approval in the producer register \\
\hline Section & Chapter 13 - supervision and administrative enforcement \\
\hline $118-122$ & Obligation to keep a record and provide information \\
\hline $123-128$ & Inspection and rectification of a violation or negligence \\
\hline $131-133$ & Penalty payment for negligence \\
\hline Section & Chapter $15-$ miscellaneous provisions \\
\hline 142 & Maintenance of waste management registers and the producer register \\
\hline Section & Chapter 16 - transitional provisions and entry into force \\
\hline 152 & Transitional period concerning an application for the producer register \\
\hline
\end{tabular}

In spite of the recent reform of the Waste Act, revisions of the Finnish waste legislation are still expected in the near future. The WEEE Directive was recast in 2012 and it provides that the WEEE Directive 2012/19/EU should be transposed into national law by February $14^{\text {th }}, 2014$, at the latest. Therefore, the Finnish Waste Act is required to be amended as well as the Government Degree on WEEE (852/2004) will need revision. According to the Ministry of Environment of Finland, the amending process of the Waste Act 646/2011 is already in progress, in such a way that circulation of a proposal for comment was carried out in June aiming at the adoption of the revised Act before the end of 2013. 


\section{Table 3}

The overview of national legislative realisation of WEEE in Finland in 2013 (Ministry of Environment of Finland, 2004 \& 2011)

\begin{tabular}{|c|c|}
\hline Key Provisions & Realisation \\
\hline Household WEEE & $\begin{array}{l}\text { Producers are responsible for organising and financing the collection of WEEE from households } \\
\text { by themselves or by jointly established corporation (producer association). Retailers must either } \\
\text { take back WEEE on a 1:1 basis, or indicate to the consumer an alternative, convenient reception } \\
\text { facility (e.g. a facility that the retailer has an agreement with). After May } 1^{\text {st }}, 2013 \text {, retailer's in- } \\
\text { store take back is obligatory and it covers also fluorescents lamps and LEDs. }\end{array}$ \\
\hline B2B WEEE & $\begin{array}{l}\text { Producers are responsible for the cost of managing non-household WEEE put on the market after } \\
\text { August } 13^{\text {th }}, 2005 \text {. They must take back products put on the market before that date on a } 1: 1 \\
\text { basis. Producers and purchasers other than households can agree on alternative arrangements } \\
\text { if they wish. }\end{array}$ \\
\hline Guarantee & $\begin{array}{l}\text { Producers that are not members of any of the producer corporations are required to provide a } \\
\text { financial guarantee assigned to the national authority on producer responsibility (ELY Centre } \\
\text { Pirkanmaa) to cover the costs incurred by waste management of equipment used in private } \\
\text { households and placed on the market by the producer. Producers that have jointly established a } \\
\text { producer association are not required to provide a separate financial guarantee because the } \\
\text { approved producer corporations must have sufficient financial resources to operate continuously } \\
\text { for at least six months. In demonstration of that, producer corporations shall report and submit } \\
\text { the action plans to ELY Centre Pirkanmaa on an annual basis. Further, a government degree will } \\
\text { be given on the calculation of producers association's guarantee and its mobilisation. }\end{array}$ \\
\hline $\begin{array}{l}\text { Producer register } \\
\text { and the national } \\
\text { authority }\end{array}$ & $\begin{array}{l}\text { As a national inspecting and controlling authority, ELY Centre Pirkanmaa maintains the } \\
\text { nationwide producer registration system for the producers' associations and for producers who } \\
\text { are not members of any compliance scheme but taking care of their producer responsibility } \\
\text { individually. It provides decisions and notifications concerning the producers register. After May } \\
1^{\text {st }}, 2013 \text {, it may also set a penalty payment for negligence to the producer or to the producer } \\
\text { association that has not registered to the producer register or fails to fulfil the required obligations. }\end{array}$ \\
\hline
\end{tabular}

\subsection{Producers associations}

In Finland, the overwhelming majority of electronic devices sold on the market are imported. Most of the representatives of foreign and domestic producers have transferred responsibility over discarded electronics to producers associations. At the moment, there are five producers associations providing centralised services to manage practical affairs related to the obligations set out in the WEEE Directive and to fulfil the corresponding obligations of Finnish legislation. Three of these associations, Finnish Lamp Importers and Producers Association (FLIP ry), ICT Producer Co-operative (ICT-tuottajaosuuskunta) and Electrical and Electronic Equipment Producers' Association (SELT ry) have joined under an umbrella organisation and service provider named Elker Ltd. in 2004. The association of Electric and Electronic Equipment Manufacturers and Importers (SER-tuottajayhteisö ry, SERTY), established in 2000, and the European Recycling Platform Finland (ERP Finland ry), established in 2005 (initially named Nordic Electronics Recycling Association, NERA ry), operate independently. In addition to being a producers association of EEE, ERP Finland is also registered as a one of the two Finnish producers associations for portable batteries and accumulators. This means the members of ERP Finland may acquire compliances for both of these product groups through a single membership. The other Finnish producer association for portable batteries and accumulators, called Recser Oy, sources services from Elker. As consequence, the members of Elker may also acquire their compliances for EEE, portable batteries and accumulators through a single practical operator, despite the memberships in two different producers associations. 
The EEE producers have organised rapidly in the very first years after the national WEEE legislation came to force in Finland (see Table 4). More than 500 producers joined the producers associations already in 2005 and, four years later, in 2009, more than 1000 companies had become members of these associations. Further, over 120 companies had registered to the producer register as individual producers for taking care of their producer responsibility independently, mainly in B2B business. In addition to the registered producers, it is estimated that free riders represent currently up to a $10 \%$ share of EEE placed on the Finnish market. No official information is available, but a common impression among producers associations is that various internet shops in particular have neglected their producer responsibility (Toppila, 2011).

\section{Table 4}

The realisation of producer responsibility on EEE in Finland in 2009 (Toppila, 2011).

\begin{tabular}{llcc}
\hline Actors & Managed WEEE streams / categories & Number of members & Market share [\%] \\
\hline Individual producers & Mainly B2B devices & 121 & 9 \\
Producers associations & & & 37 \\
$\quad$ SERTY & Categories 1-10 & 120 & 29 \\
Elker group & Categories 1-10 & & \\
SELT & Categories 1, 2, 6-10 & 673 & \\
ICT & Categories 3, 4 & 245 & \\
FLIP & Category 5 & 14 & 25 \\
ERP Finland & Categories 1-10 \& Portable batteries and & 20 & \\
& accumulators & & \\
\hline
\end{tabular}

\section{$4 \quad$ The Finnish WEEE recovery infrastructure}

\subsection{Nationwide collection network}

Prior to the implementation of the WEEE Directive, operational preconditions to a nationwide, separate collection and recovery system of WEEE did not exist in Finland. However, a high proportion of discarded metal-rich large household appliances such as refrigerators, kitchen stoves and washing machines were already recycled even prior to 2003, because most of the electronic goods retailers took back old equipment when buying a new one and paying a discard fee. Individual citizens could also take their end-of-life equipment to designated reception places, such as waste management centres, in the largest cities of Finland.

To fulfil the requirements set in the WEEE Directive, a recovery infrastructure needed to be built in Finland after 2003. Separate collection and transportation are generally the most expensive steps of the WEEE reverse supply chain and, therefore, it is crucial to set up an efficient collection system (Achillas et al., 2010; Lonn et al., 2002). In general, separate waste collection channels can be classified as drop-off programmes, pick-up programmes and distance collection. All these channels are typically used also for WEEE. In drop-off programmes, consumers can return discarded devices to permanent collection centres, retailers or to containers located in the public places such as in the streets. Drop-off collection programmes can also be implemented as temporary collection events. WEEE can also be collected from last users through pick-up programmes or distance collection, such as when WEEE is sent through postal services (Chancerel, 2010). Globally, the most commonly used methods of implementing the producer responsibility of WEEE are permanent collection points located at municipal sites, in-store retailer take-back and direct producer takeback (Savage et al., 2006; Sthiannopkao and Wong, 2013).

In Finland, collection of WEEE is arranged mainly as a permanent collection. In the building phase of the recovery system, two diverse structures of the WEEE supply chain were formed. SERTY and NERA (current 
ERP Finland) built both their own centralized reverse supply chains, where WEEE was transported nationally from collection points to only a few treatment points. Elker Oy, for one, promoted a nationwide decentralised logistics network with over 30 pre-treatment stations and several transport service providers across the country. After the first operating years, producers associations have begun to collaborate more and, in consequence, SERTY and ERP Finland have also moved towards a more decentralised system with several regional contractors. At the present, clauses on cooperation between producers associations were put to the Finnish Waste Act 646/2011, to ensure overall functioning of the producer responsibility systems, instead of hampering parallel waste management or re-use systems.

In the implementation phase of the WEEE Directive, the Finnish inspecting and controlling authority of WEEE, the ELY Centre Pirkanmaa set requirements for the extent and coverage of the permanent collection network. The minimum requirement of a convenient nationwide network is 340 permanent reception points in 235 municipalities and it has been applied to each producers association separately. Nowadays, most of the reception points are collectively financed by the producers associations and, therefore, there were a total of 451 reception points in 277 Finnish municipalities in 2011 (Toppila, 2011). The management of these points are provided chiefly by municipal waste companies and are typically located in the premises of said companies. In some cases, reception points can also be provided by private companies or social economy enterprises.

The permanent collection point network in Finland is quite similar to collection systems in many European countries, e.g. in Denmark (Grunow and Gobbi, 2009), Italy (Gamberini et al., 2010), Portugal (Gomes et al., 2011) and Sweden (Bernstad et al., 2011). However, permanent collection systems are not efficient in all cases, due to e.g. long distances and low quantities of returned devices (Barba-Gutiérrez et al., 2008; Kang and Schoenung, 2005). Therefore, in the 50 smallest or most sparsely populated municipalities of Finland, the recovery of WEEE is organised as a mobile collection, typically once or twice a year. In case of mobile collection, producers associations appoint the dates and places case-specifically with the municipality in question. After the dates are set, the municipalities or regional waste management companies inform local inhabitants of all practical issues through internet pages, local newspapers and hand-outs distributed to the households.

Until these days, the use of retailers' take-back option has been very limited in Finland due to strong resistance the Finnish retail business. However, trials of WEEE collection in retail shops have been carried out over the last years in a few, most sparsely populated municipalities in Lapland due to the lack of permanent collection points and relatively seldom realised mobile collection. However, in accordance with the Directive 2012/19/EU, the retailer take-back option has been extended throughout Finland. Since May $1^{\text {st }}, 2013$, EOL EEE devices can also be returned to the retailers in association with buying a new, corresponding device, to the store the new device is bought at. Since that date, small WEEE (all dimensions no more than $25 \mathrm{~cm}$ ) can be returned also with no purchase obligation to electronics shops larger than $200 \mathrm{~m}^{2}$ or to grocery shops with the minimum area of $1000 \mathrm{~m}^{2}$. Additionally, fluorescent lamps and LEDs as well as portable batteries and accumulators can also be returned to the retail shops with no purchasing obligations. Stores are required to finance and organise the place, requisites and work contributions needed to receive the WEEE. Distributors may forward the received WEEE to the reception points of official collection network by themselves or, alternatively, they may enrol in a distributors register in order to obtain free unloading services financed by producers associations. After registration, distributors may also purchase certain combo receivers designed 
especially for small WEEE or get free of charge a special collection requisite for data WEEE, if such kinds of devices are included in the distributor's product range.

The EOL devices from private users and households can be brought to the reception points and stores free of charge. Non-private users, such as enterprises and institutes, are generally not allowed to return WEEE to these points. It is recommended that they make an individual contract with the regional operators, to remove and take care of their electronic equipment. However, in case of moderate amounts of consumer WEEE being used in the companies, those can be returned to the certain B2B reception points managed by the producers associations. These points are typically located in connection with the sorting and pre-treatment plants of private service providers and they are also open for private consumers with larger batches of household WEEE. In addition, some direct producer take-back schemes also exist in Finland, concerning EEE devices intended only for business use.

In the Finnish WEEE recovery system, transportation of WEEE from reception points and registered stores to the regional treatment plants is managed by the producer associations. The logistics services are typically sourced from private regional operators. At the regional handling plants, functional devices are separated and directed for preparation for re-use. The rest of the WEEE is sorted out according to WEEE categories and is pre-treated before sending to the various treatment plants for final treatment. The companies offering sorting and dismantling services to producers associations are typically social economy enterprises but a few private companies also exist in the field. Some of the dismantling and pre-treatment plants provide also final treatment services for particular WEEE fractions; however, most of the sorted and pre-treated WEEE is forwarded to detached recovery and/or final treatment plants located mainly in Finland. The main steps of the WEEE recovery network in Finland are presented in Fig. 1.

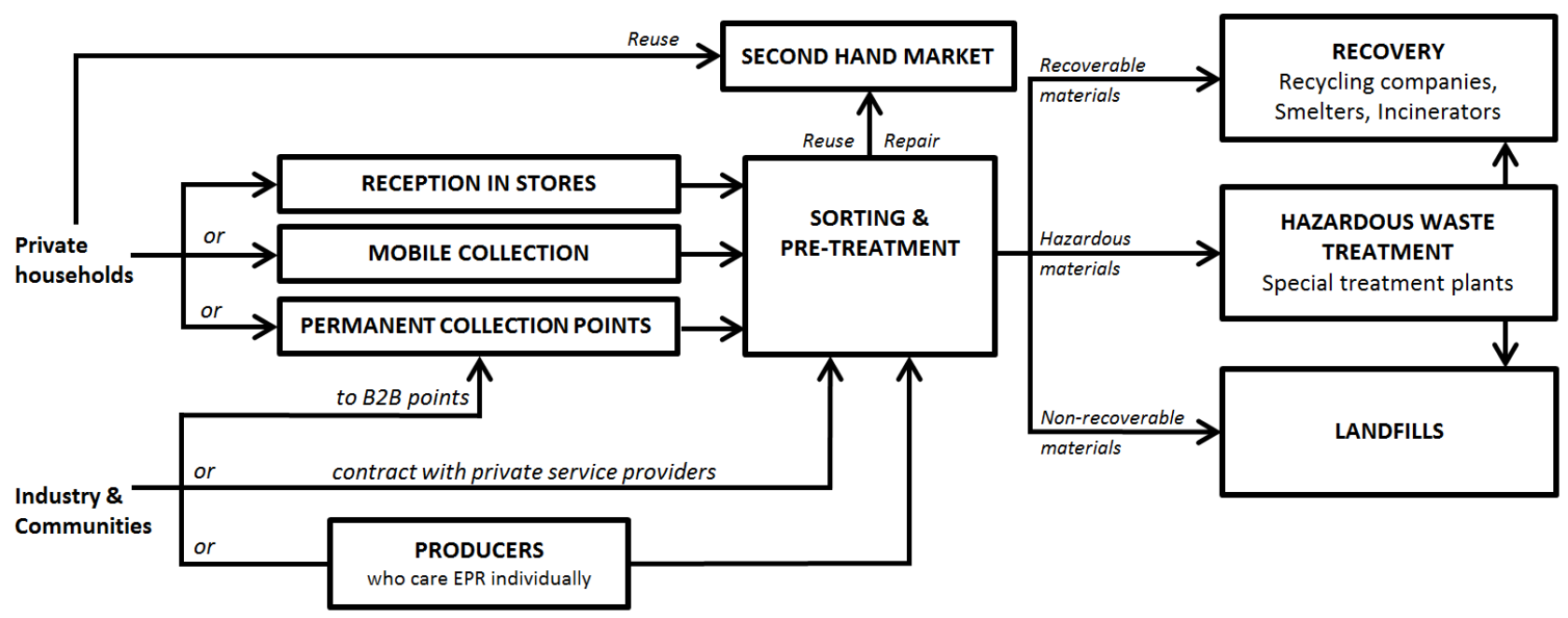

Fig. 1. The main steps of the Finnish WEEE recovery network.

\subsection{Realisation of a regional WEEE recovery network: case Oulu}

In the Oulu Region, the municipal waste management system is managed by the Oulu Waste Management Company, which is responsible for municipal waste in the operation area of 12 municipalities, serving over 285,000 residents in 2013. In order to promote households recycling activities, the Oulu Waste Management Company has around 70 collection points in its area of operation to facilitate separate collection 
of domestic recyclables such as cardboard, glass, metal and paper. Moreover, there are also several waste stations where particular special domestic wastes such as hazardous wastes, WEEE and small amounts of waste oils are received for free.

In the case of WEEE, the Oulu Waste Management company has identical contracts with producers associations of SERTY, ERP Finland and Elker group to maintain a total of 11 permanent reception points in its operating area. All these reception points are manned with fixed opening times and guidance is available on demand. The main reception point of WEEE is situated in the Rusko Waste Centre in the premises of the Waste Management Company in Oulu. In the premises, WEEE is roughly sorted by consumers when the EOL devices are returned to the designated containers and cages in the area. The rest of the 10 reception points are situated on the company's waste stations in rural population centres of the Oulu Region. In those reception points, the returned EOL devises are put into a single container or cage without sorting, whilst awaiting delivery to the regional sorting and pre-treatment plant. WEEE will then be sorted and manually disassembled to fulfil requirements for selective treatment set in the Annex II of the WEEE Directive. In addition to the reception points maintained by the Oulu Waste Management Company, consumers can also return the EOL devices to the reception points located in the premises of WEEE pre-treatment operators in the Oulu Region or stores with certain limitations.

From the collection points, WEEE is transported by private transportation providers contracted by producers associations to the regional sorting and pre-treatment station situated in the city of Oulu. In the sorting plant, WEEE is separated for different product co-operatives, weighed and sorted into re-usable and not re-usable ones. Re-usable equipment or components are disassembled, stocked and delivered onwards. Further, the pre-treated recyclable devices and materials are delivered for treatment and material recovery mainly in Finland (see Fig. 2) while non-recyclable WEEE is stocked in the pre-treatment station until it is delivered to the final treatment plants or disposed. Data on the quantities of various WEEE fractions and operations performed in the sorting and pre-treatment station are sent to the producers' co-operatives.

According to the Oulu Waste Management Company, the current regional collection system of WEEE is functional and qualifies well in its task. The quantities of WEEE disposed with mixed municipal waste in Oulu are at the same level as in the Helsinki Capital Region (on average $1.5 \mathrm{~kg} /$ inhab./year in 2012 (Pulkkinen and Sinisalo, 2012)). Additionally, collected amounts and recovery rates in Oulu region are matching Finnish average levels, even though distances from rural households to the nearest reception point might be more than $50 \mathrm{~km}$. 


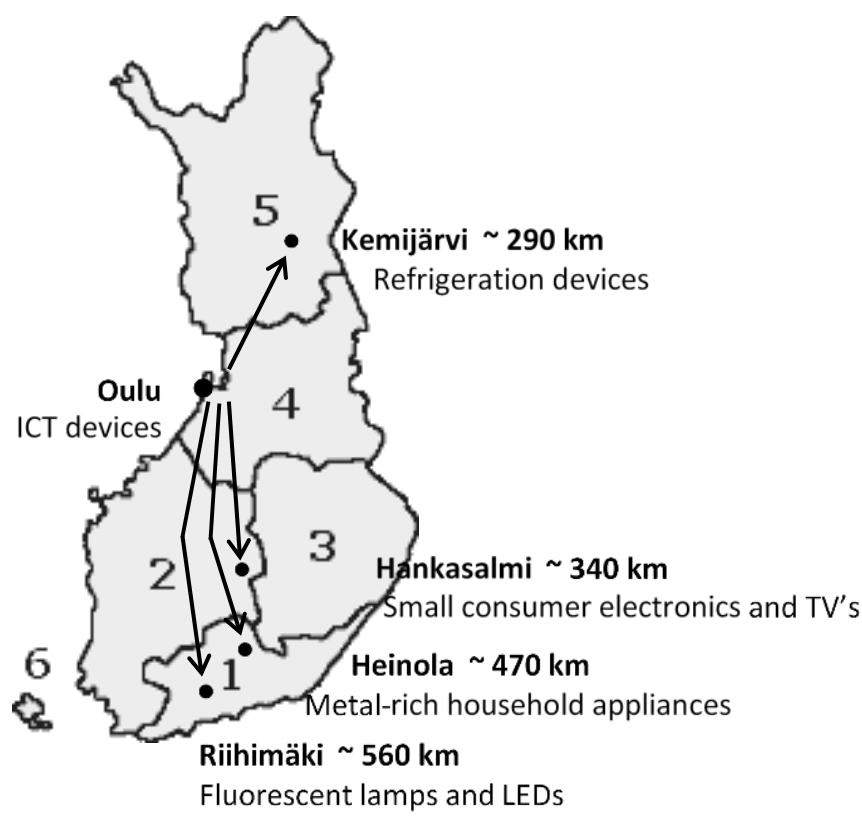

Fig. 2. The course of pre-treated WEEE from reception points maintained by the Oulu Waste Management.

\subsection{Achievement of the WEEE Directive targets in Finland}

The latest official data from the Finnish producer registration system reported to the EU is from the year 2010. According to the statistics (Eurostat, 2013), more than 50,000 tonnes or some $9.5 \mathrm{~kg} /$ person/year of WEEE were collected separately in Finland. Almost $87 \%$ of collected WEEE was treated inside the country and, further, approximately $13 \%$ was shipped to another EU member state for final treatment. Only $0.2 \%$ was reported to be treated outside the EU. Most of the collected WEEE, 88.1\%, was recycled as materials and, in addition, only a minor proportion, less than $0.4 \%$, was re-used as parts or as whole equipment. Re-use and recycling rate was, therefore, close to $88.5 \%$. Further, approximately $3.1 \%$ of WEEE was recovered as energy. The total rate of WEEE recovery in Finland was, therefore, almost 92\%. Targets set down in the WEEE Directive for re-use, recycling and recovery of WEEE were, therefore, fulfilled in every category (see Table 5) (Eurostat, 2013).

\section{Table 5}

Amounts of collected WEEE and achieved recovery and recycling rates in Finland in 2010 (Eurostat, 2013).

\begin{tabular}{llllll}
\hline & Categories & $\begin{array}{l}\text { Amount } \\
\text { [tonnes] }\end{array}$ & $\begin{array}{l}\text { Portion } \\
{[\text { w\%] }}\end{array}$ & $\begin{array}{l}\text { Actual recovery/ } \\
\text { target [\%] }\end{array}$ & $\begin{array}{l}\text { Actual re-use and recycling/ } \\
\text { target [\%] }\end{array}$ \\
\hline 1 & Large household appliances & 27,698 & 54.5 & $93 / 80$ & $88 / 75$ \\
2 & Small household appliances & 1320 & 2.6 & $84 / 70$ & $82 / 50$ \\
3 & IT and telecom equipment & 8034 & 15.8 & $92 / 75$ & $92 / 65$ \\
4 & Consumer electronics & 12,117 & 23.8 & $90 / 75$ & $88 / 65$ \\
5 & Lightning equipment & 961 & 1.9 & $91 / 70$ & $86 / 50$ \\
6 & Electrical and electronic tools & 276 & 0.5 & $94 / 70$ & $98 / 50$ \\
7 & Toys, leisure and sports devices & 99 & 0.2 & $84 / 70$ & $82 / 50$ \\
8 & Medical devices & 53 & 0.1 & $75 /-$ & $75 /-$ \\
9 & Monitoring and control instruments & 119 & 0.2 & $78 / 70$ & $76 / 50$ \\
10 & Automatic dispensers & 189 & 0.4 & $98 / 80$ & $78 / 75$ \\
& Total/average & 50,867 & 100.0 & 91.5 & 88.5 \\
\hline
\end{tabular}


Despite the good annual WEEE recovery and recycling rates, the tendency of collected and treated WEEE amounts in Finland has decreased in the past years (see Figure 3). There is no single explanation to this phenomenon but it can be expected that the amounts of historic WEEE (WEEE generated prior to the recovery system and stored years in consumers' warehouses) has started to diminish after the first few years of free returning possibilities of WEEE. The other conceivable reason might be increasing leakage outside the official recovery system, due to continuously rising metal prices. Also the instability of European and world economy might have weakened people's eagerness to replace functional devices by newer models, which may have also contributed to the decreasing tendency. A similar trend has also been observed in Sweden in 2008 (Bernstad et al., 2011). Even though the phenomenon has been interpreted in Sweden as an effect of the economic recession, Bernstad et al. (2011) suggested that the trend towards smaller and more light-weight electronic devices might have also an impact on the decreasing tendency.

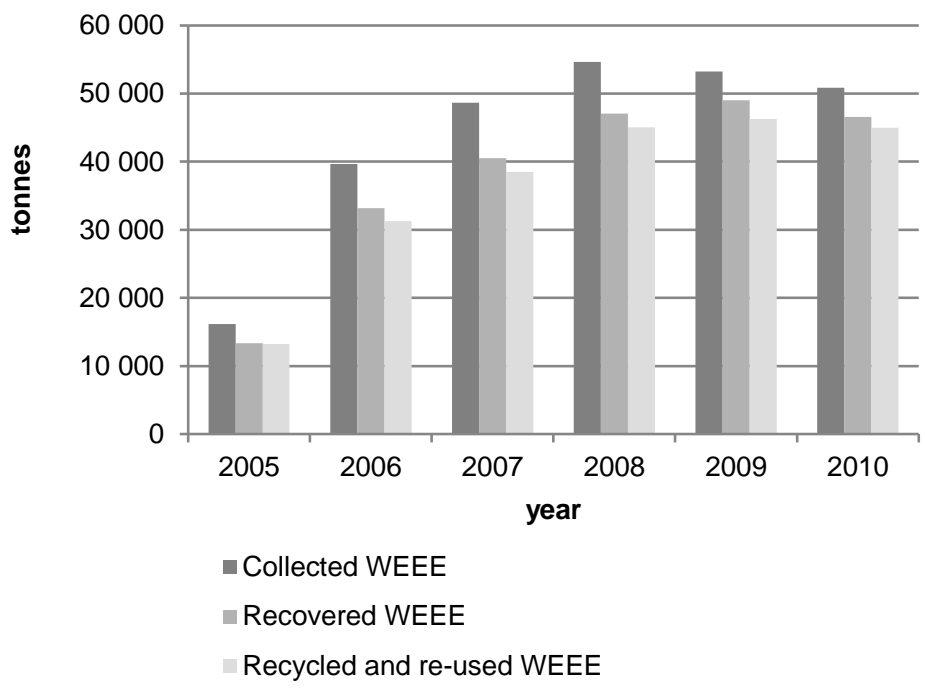

Fig. 3. Amounts of officially collected and treated WEEE in Finland during 2005-2010 (Eurostat, 2013).

\section{Evaluation of the WEEE recovery system in Finland and challenges to its effective management}

The main challenges of WEEE collection rise from the contradiction between legislation and the benefits of the producers. For reasons of efficiency, WEEE re-use should take place as much upstream as possible, in order to send re-usable appliances to adequate re-use channels without damages. However, producers may regard re-use and remanufacturing as a conflict of interests; the total sales may be increased through a better environmental image or, to the contrary, remanufacture of EEE appliances may reduce sales volumes of new equipment in parallel with increasing the costs of WEEE collection. In addition, in some cases, it is suggested that the image of remanufacturing can also hurt the brand image of companies producing high-tech fashionconscious devices (Herold, 2007).

Despite the goal of the EU and Finnish WEEE legislation to prevent waste generation and promote reuse, recycling and other forms of recovery of such waste, the current Finnish recovery system of WEEE does not promote the re-use and/or refurbishment of EEE. Above all, the re-use potential of the EOL electronics is significantly underused in Finland, not only in the case of devices returned to the recovery system but also in 
cases when unused devices lay around in households storages. At this moment, it seems the information and guidance in collection points is inadequate in Finland and the remaining re-use potential of unused devices is lost due to inappropriate handling in reception points and in the transportation phase. In order to enhance reuse, separate collection for re-usable equipment should be intensified and, in addition, testing and refurbishing system should be established in connection with WEEE collection. Moreover, the market of re-used and/or refurbished EEE needs to expand in Finland and also a change in consumer attitudes is required. Based on the WEEE recovery experiences of other Nordic countries, it can be expected that raising consumer awareness will lead to environmentally sound behaviour and, ultimately, improve WEEE recovery efficiency.

WEEE legislation provides a reasonable opportunity to return discarded appliances for recovery throughout the country. However, the main challenges to the development of a nationwide collection network are related to long transportation distances and sizes of permanent collection points. In the smallest reception points, the physical space of collection cages are limited and the amounts of returned WEEE may vary substantially due to larger batches of WEEE from rural households. It may lead to careless handling and inappropriate storing conditions while waiting transportation. Use of suitable containers and sorting opportunities also in the smallest points would improve cost-effectiveness of the collection and transportation phases (Gamberini et al., 2009; Krook and Eklund, 2010). Long transportation distances, especially in the northernmost parts of Finland, bring challenges to managing the WEEE recovery system effectively. The value of materials contained in WEEE also substantially affects to the profitability of recovery. For example, appliances containing many valuable materials, e.g. precious metals, have a considerable market value and, therefore, they are typically in the focus on recycling. At the same time, appliances containing only few valuable components but high transportation and treatment costs, such as refrigerators and other large household appliances, may even have negative value. Therefore, the collection and transportation stages of WEEE, especially those of low re-use value categories, should be minimised by improving the decentralised pretreatment stations network across the country and optimising the collection from a cost-effectiveness point of view.

Legislation also highlights that private consumers and households are able to dispose of WEEE free of charge, while industry, educational institutes and communities may have to pay for it. However, as experienced by Finnish producer associations, it seems that some companies are not yet familiar with this part of the legislation and are using the free-of-charge channels reserved for private consumers. In addition, some free and easy rider companies, who have not registered to the producer register and do not attend to their responsibility, still exist in Finland. The Finnish national inspecting and controlling authority of WEEE, ELY Centre Pirkanmaa, has informed and guided the companies over the years but more information and publicity on current changes of WEEE legislation and prevailing practices are still needed. For intervening in free riding, the role of ELY Centre Pirkanmaa has recently been enhanced by law. Since May $1^{\text {st }}, 2013$, it has a mandate to impose a penalty payment for negligence on demand. A case-specific penalty payment is always imposed as a final coercive measure to alter the current state of affairs, and its amount depends on the turnover of the company or the quality and extent of negligence in question. To date, no penalty payments have yet been imposed, due to novelty of this enactment.

The other remarkable challenge of the current system is the collection points outside the official network. In these unofficial collection points, only the most valuable WEEE is received, while WEEE with low or negative value is left at the responsibility of producers associations. This unhealthy competition in WEEE collection and 
recovery resulted in increased operational costs and, further, decrease in the cost-effectiveness of WEEE recovery network under producer responsibility. As a measure to restrict this tendency, the producer's right of precedence to organise waste management covered by producer responsibility has been included in the reformed Waste Act, which took effect in 2012. This means that other operators than producers may establish parallel collection or reception systems for discarded products, or provide related services only if those are managed in cooperation with the producer or producer association. At this moment, it has had no noticeable effect yet on the amount of officially collected WEEE, due to the transitional period of the law. However, the amounts and the profitability of WEEE received by producers associations are expected to rise in the near future, in consequence to the producer's right of precedence to waste management and also because of the upcoming distributors' take-back obligations.

The Finnish WEEE legislation is currently in a transient phase, due to the Waste Act being under reform and the recast of the WEEE Directive resulting in the revision of the Government Degree on WEEE. Therefore, providing up-to-date information and increased publicity on prevailing practices would be actual at this current stage. In addition, extensive and nationwide information campaigns on upcoming changes are highly recommended.

\section{Conclusions}

The purpose of this paper was to provide a comprehensive overview of the implementation of the WEEE Directive in Finland, and evaluate it from the point of resource efficiency. The development of the Finnish WEEE recovery system is reviewed, to identify successful and efficient factors as well as inefficient practices. Based on this study, it can be concluded that the implementation of the WEEE Directive and development of the WEEE recovery infrastructure has succeeded in Finland. At the same time as the legislative basis has been enacted, a functional infrastructure has been built successfully in a relatively short time. Nowadays, there are approximately 450 permanent WEEE reception points in more than 270 Finnish municipalities. Additionally, WEEE collection is also organised as a mobile collection in the 50 smallest or least populous municipalities of Finland. In addition, the amounts of reception in retail stores have also been on to rise. In addition to the development of a functional nationwide collection network, the collection requirements of the Directive have clearly been exceeded and Finland has managed to achieve good recovery percentages in a few years. Since 2007, the WEEE collection rate in Finland has exceeded $9 \mathrm{~kg} / \mathrm{inhab} . / y e a r$ and stands as the third best in the context of European Union despite of wide, sparsely populated areas in the Northern and Eastern parts of Finland. Therefore, we believe the WEEE collection system as established in Finland has evidently advantages, which can be considered by countries implementing national WEEE legislation or setting up WEEE collection networks.

In spite of good WEEE recovery customs in Finland, some inefficient practices still exist, particularly at the registration and collection stages. The main challenges are related to the sizes of permanent collection points. In the smallest reception points, the physical spaces of collection cages are limited and the amounts of returned WEEE may vary substantially, causing careless handling and inappropriate storage conditions. In addition to challenges of the official system, free riding companies and unofficial collection points create increasing concern for functionality and cost-effectiveness of the current system.

Finnish WEEE legislation is currently in a transient phase and, therefore, up-to-date information and increased publicity on prevailing practices are needed to raise public awareness related to WEEE in Finland. 
It is expected that raising awareness will further lead to environmentally sound behaviour in the long run and, ultimately, improve WEEE recovery efficiency.

\section{Acknowledgements}

The financial support of the Finnish Doctoral Programme in Environmental Science and Technology (EnSTe) and Thule Institute's Doctoral Program at the University of Oulu are gratefully acknowledged. Authors also thank MA in English philology, Ms. Heidi Pruikkonen for proof-reading and linguistic corrections of the text.

\section{References}

Achillas Ch, Vlachokostas Ch, Aidonis D, Moussiopoulos N, lakovou E, Banias G. Optimising reverse logistics network to support policy-making in the case of Electrical and Electronic Equipment. Waste Management 2010;30:2592-600.

Barba-Gutiérrez Y, Adenso-Díaz B, Hopp M. An analysis of some environmental consequences of European electronic waste regulation. Resources, Conservation and Recycling 2008;52:481-95.

Bernstad A, la Cour Jansen J, Aspegren H. Property-close source separation of hazardous waste and waste electrical and electronic equipment - a Swedish case study. Waste Management 2011;31:536-43.

Chancerel P. [Doctoral Dissertation] Substance flow analysis of the recycling of small waste electrical and electronic equipment - an assessment of the recovery of gold and palladium [Doctoral Dissertation]. Institut für Technischen Umweltschutz, Technischen Universität Berlin, Germany; 2010. p. 161.

Darby L, Obara L. Household recycling behaviour and attitudes towards the disposal of small electrical and electronic equipment. Resources, Conservation and Recycling 2005;44:17-35.

Directive 2002/96/EC of the European Parliament and of the Council of 27 January 2003 on Waste Electrical and Electronic Equipment. Official Journal 13.2.2003;L37.

Directive 2012/19/EU of the European Parliament and of the Council of 4 July 2012 on waste electrical and electronic equipment (WEEE). Text with EEA relevance. Official Journal 24.7.2012;L197.

European Commission. Commission staff working paper \{SEC(2008) 2933\}; 2008.

Eurostat, Environmental data centre on waste - Waste Electrical and Electronic Equipment (WEEE); 2013, http://epp.eurostat.ec.europa.eu/portal/page/portal/waste/key_waste_streams/waste_electrical_electroni C_equipment_weee [accessed 08.04.13 and 27.11.13].

Gamberini R, Gebennini E, Grassi A, Mora C, Rimini B. An innovative model for WEEE recovery network management in accordance with EU directives. International Journal of Environmental Technology and Management 2008;8:348-68.

Gamberini R, Gebennini E, Rimini B. An innovative container for WEEE collection and transport: details and effect following adoption. Waste Management 2009;29:2846-58.

Gamberini R, Gebennini E, Manzini R, Ziveri A. On the integration of planning and environmental impact assessment for a WEEE transportation network - a case study. Resources, Conservation and Recycling 2010;54:937-51.

Gomes MI, Barbosa-Povoa AP, Novais AQ. Modelling a recovery network for WEEE: a case study in Portugal. Waste Management 2011;31:1645-60. 
Grunow M, Gobbi C. Designing the reverse network for WEEE in Denmark. CIRP Annals - Manufacturing Technology 2009;58:391-4.

Gutiérrez E, Adenso-Días B, Lozano S, González-Torre P. A competing risks approach for time estimation of household WEEE disposal. Waste Management 2010;30:1643-52.

Herold M. [Doctoral Dissertation] A Multinational perspective to managing end-of-life electronics [Doctoral Dissertation]. Espoo, Finland: Helsinki University of Technology; 2007. p. 253.

Huisman J, Magalini F, Kuehr R, Maurer C, Delgado C, Artim E, et al. 2008 Review of Directive 2002/96 on Waste Electrical and Electronic Equipment (WEEE). In: United Nations University, Bonn, Germany; 2007.

Kang HY, Schoenung JM. Electronic waste recycling: a review of U.S. infrastructure and technology options. Resources, Conservation and Recycling 2005;45:368-400.

Krook J, Eklund M. The strategic role of recycling centres for environmental performance of waste management systems. Applications of Ergonomics 2010;31:536-43.

Li J, Lopez N, Liu BN, Zhao L, Yu N, Zheng LK. Regional or global WEEE recycling. Where to go? Waste Management 2013;33:923-34.

Lonn SA, Stuart JA, Losada A. How collection methods and E-commerce impact product arrival rates to electronics return, reuse, and recycling centers. In: Proceedings of IEEE International Symposium on Electronics and the Environment; 2002. p. 228-33.

Melissen FW. Redesigning a collection system for "small" consumer electronics. Waste Management 2006;26: 1212-21.

Ministry of the Environment in Finland. Waste Act 1072/1993; amendments up to 1063/2004 included; 2004, http://www.finlex.fi [accessed 02.11.06].

Ministry of the Environment in Finland. Waste Act 646/2011; amendments up to 195/2012 included; 2011, http://www.finlex.fi [accessed 04.04.13].

Nnorom IC, Osibanjo O. Overview of electronic waste (e-waste) management practices and legislations, and their poor applications in the developing countries. Resources, Conservation and Recycling 2008;52:84358.

Ongondo FO, Williams ID. Mobile phone collection, reuse and recycling in the UK. Waste Management 2011;31:1307-15.

Papaoikonomou K, Kipouros S, Kungolos A, Somakos L, Aravossis K, Antonopoulos I, et al. Marginalised social groups in contemporary WEEE management within social enterprises investments: a study in Greece. Waste Management 2009;29:1754-59.

Pérez-Belis V, Bovea MD, Gómez A. Waste electric and electronic toys: management practices and characterisation. Resources, Conservation and Recycling 2013;77:1-12.

Polák M, Drápalová L. Estimation of end of life mobile phones generation: the case study of the Czech Republic. Waste Management 2012;32:1583-91.

Pulkkinen S, Sinisalo S. Quality and quantity of household mixed solid waste in the Helsinki metropolitan area 2012. Finland: HSY publications 2/2013, Helsinki Region Environmental Services Authority; 2012 [in Finnish].

Queiruga D, González Benito J, Lannelongue G. Evolution of the electronic waste management system in Spain. Cleaner Production 2012;24:56-65. 
Savage M, Ogilvie S, Slezak J, Artim E. Implementation of waste electric and electronic equipment directive in EU. European Commission, Directorate General, joint Research Centre; Institute for Prospective Technological Studies. Luxemburg: Office for Official Publications of the European Communities; 2006. http://ftp.jrc.es/EURdoc/eur22231en.pdf [accessed 16.04.13]

Sinha-Khetriwal D, Widmer R, Schluep M, Eugster M, Wang X, Lombard R, et al. Legislating e-waste management: progress from various countries. Environmental Law Network International Review 2006;1+2/06:27-36.

Sinha Khetriwal D, Widmer R, Kuehr R, Huisman J. One WEEE, many species: lessons from the European experience. Waste Management \& Research 2011;29:954-62.

Statistics Finland. Finland in figures; 2013, http://www.tilastokeskus.fi [accessed 04.04.13].

Sthiannopkao S, Wong M.H. Handling e-waste in developed and developing countries: initiatives, practices and consequences. Science of the Total Environment 2013;463-464:1147-53.

Toppila A. [Master's Thesis] Waste flows in Finnish Producer Responsibility System - case WEEE and portable batteries and accumulators [Master's Thesis]. Finland: University of Jyväskylä, 2011 [in Finnish].

Torretta V, Ragazzi M, Istrate IA, Rada EC. Management of waste electrical and electronic equipment in two EU countries: a comparison. Waste Management 2013;33:117-22.

Turner M, Callaghan D. Waste Electrical and Electronic Equipment Directive - UK to finally implement the WEEE Directive. Computer Law \& Security Report 2007;23:73-6.

Walther G, Steinborn J, Spengler TS, Luger T, Herrmann C. Implementation of the WEEE-directive - economic effects and improvement potentials for reuse and recycling in Germany. Advanced Manufacturing Technology 2010;47:461-74. 